\title{
Complete mitochondrial genome of the endangered species
}

\section{Brycon nattereri (Characiformes, Characidae) [version 1; peer}

\section{review: 2 approved with reservations]}

\section{Snaydia Viegas Resende (Di)1, Rubens Pasa(D1, Fabiano Bezerra Menegídio (D)2, John Seymour (Pat) Heslop-Harrison ${ }^{3}$, Trude Schwarzacher ${ }^{3}$, Karine Frehner Kavalco (D)1}

\footnotetext{
${ }^{1}$ Laboratory of Ecological and Evolutionary Genetics, Federal University of Viçosa, Rio Paranaíba, Minas Gerais, 38810-000, Brazil

${ }^{2}$ Integrated Nucleus of Biotechnology, University of Mogi das Cruzes, Mogi das Cruzes, São Paulo, 08780-911, Brazil

${ }^{3}$ Department of Genetics and Genome Biology, University of Leicester, Leicester, UK
}

V1 First published: 18 Nov 2020, 9:1343

https://doi.org/10.12688/f1000research.26524.1

Latest published: 18 Nov 2020, 9:1343

https://doi.org/10.12688/f1000research.26524.1

\begin{abstract}
Brycon nattereri is a Brazilian fish species of the order Characiformes (Bryconidae). Like others in the genus, B. nattereri is classified as "vulnerable" on the red list of endangered species. For this work, we collected a sample of $B$. nattereri from the Upper Paraná and São Francisco river basins, identified it and registered in an ichthyology collection. Whole genome sequencing was performed by Illumina. The raw reads were assembled with Novoplasty and the sequence annotated with MitoAnnotator. This is the third complete mitochondrial genome described for the genus and is available on GenBank: MT428073.1 and MT428074.1.
\end{abstract}

Keywords

WGS, Genomics, mitDNA, mitogenome

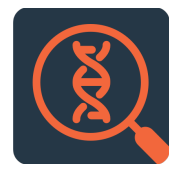

This article is included in the Genomics and

Genetics gateway.

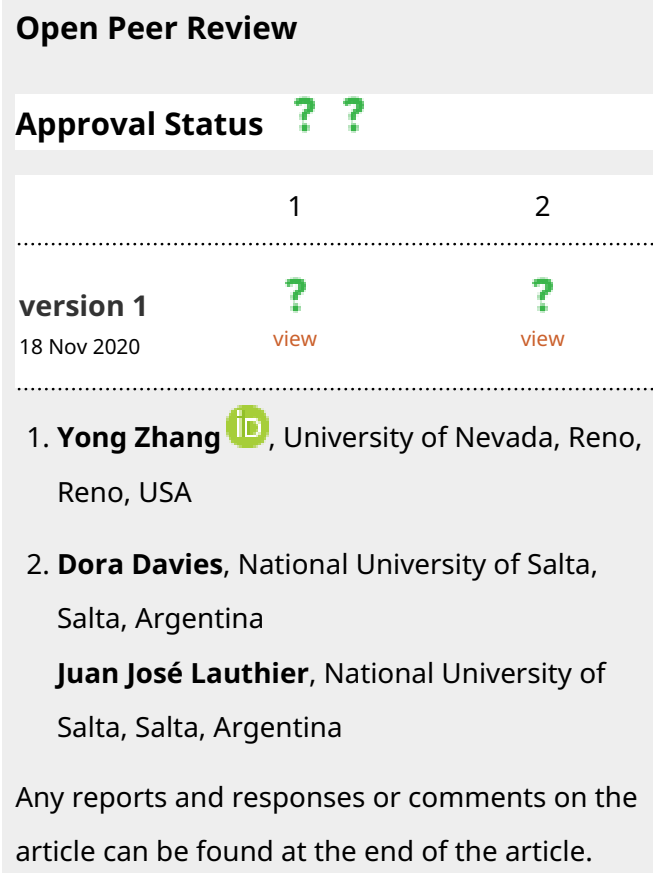

2. Dora Davies, National University of Salta,

Salta, Argentina

Juan José Lauthier, National University of

Salta, Salta, Argentina

Any reports and responses or comments on the article can be found at the end of the article. 
Corresponding author: Snaydia Viegas Resende (snaydiaresende@gmail.com)

Author roles: Resende SV: Conceptualization, Data Curation, Formal Analysis, Methodology, Validation, Visualization, Writing - Original Draft Preparation, Writing - Review \& Editing; Pasa R: Conceptualization, Data Curation, Formal Analysis, Funding Acquisition,

Methodology, Project Administration, Resources, Supervision, Validation, Writing - Review \& Editing; Menegídio FB: Conceptualization,

Data Curation, Formal Analysis, Methodology, Software, Validation; Heslop-Harrison JS(: Funding Acquisition, Resources; Schwarzacher

T: Funding Acquisition, Resources; Kavalco KF: Conceptualization, Formal Analysis, Project Administration, Resources, Supervision,

Validation, Visualization

Competing interests: No competing interests were disclosed.

Grant information: The author(s) declared that no grants were involved in supporting this work.

Copyright: ( 2020 Resende SV et al. This is an open access article distributed under the terms of the Creative Commons Attribution License, which permits unrestricted use, distribution, and reproduction in any medium, provided the original work is properly cited.

How to cite this article: Resende SV, Pasa R, Menegídio FB et al. Complete mitochondrial genome of the endangered species Brycon nattereri (Characiformes, Characidae) [version 1; peer review: 2 approved with reservations] F1000Research 2020, 9:1343

https://doi.org/10.12688/f1000research.26524.1

First published: 18 Nov 2020, 9:1343 https://doi.org/10.12688/f1000research.26524.1 


\section{Introduction}

Brycon Müller \& Troschel 1844 has 44 valid species and belongs to the order Characiformes. Species vary between medium and large size and are found in the hydrographic basins of South America and the Caribbean (Lima, 2017). Brycon, Chilobrycon, Henochilus and Salminus belong to the family Bryconidae (Abe et al., 2014). They occur in rivers of clean, flowing water, with a rock bed and high levels of oxygen (Botero-Botero \& Ramírez-Castro, 2011). Dependent on the riparian forest, for the most part they feed on allochthonous material, such as fruits, seeds and insects (Albrecht et al., 2009). Seven species of the genus are threatened, including Brycon nattereri, and the main reasons are fishing and environmental changes (Pavanelli et al., 2018). B. nattereri occurs in the Tocantins, Paraná and São Francisco river basins. Chromosome, molecular and population studies with specimens from tributaries of the last two river basins showed significant differences between individuals from different basins (Resende et al., 2020). B. nattereri would be the third complete mitochondrial genome sequenced in the genus, after $B$. orbignyanus and $B$. henni.

\section{Methods}

The two B. nattereri specimens used in this work was collected in the Salto Stream (19 27'54.9” S; 46 13'57.2" W) and Espinha Stream (19 02 '32.8'S; 46 $\left.01^{\prime} 12.9^{\prime \prime} \mathrm{W}\right)$ tributaries belonging to the Paraná and São Francisco River basins, respectively, from Minas Gerais State, Brazil.

After sampling, we brought the living specimens to the laboratory, euthanized them according to the technical standards of CONCEA (National Council for Control of Animal Experimentation of Brazil and CEUA/UFV) and the Animal Use Ethics Committee/Federal University of Viçosa (883/2019). We performed the sampling with licenses provided by SISBIO (Biodiversity Authorization and Information System; license number: 1938128) and SISGEN (National System for the Management of Genetic Heritage and Associated Traditional Knowledge; license number: A9FE946). We identified and deposited the specimens in the ichthyological collection of the Laboratory of Ecological and Evolutionary Genetics of the Federal University of Viçosa, Rio Paranaíba campus (voucher number: LaGEEvo-3928 and LaGEEvo-3847).

Total genomic DNA was extracted from liver and heart samples, as per the instructions of Invitrogen's DNA extraction and purification kit (catalog number: K182002). After quality checking using Nanodrop (Lite Spectrophotometer ND-LITE-PR), Whole Genome Sequencing was performed by Illumina sequencing (San Diego, CA) at Novogene company, UK. The $2 \times 150$ raw reads were uploaded to Galaxy
(Afgan et al., 2018), and trimmed to remove the adaptors and low-quality sequences using Trimmomatic Galaxy Version 0.38.0 (Bolger et al., 2014).

We assembled the mitogenome from raw reads on NOVOPlasty v3.7 (Dierckxsens et al., 2017) in a parallel cluster computer (64 Gb RAM) using the mitogenome of Brycon henni (GenBank KP027535.1) as seed. The mitogenome of Brycon from the Parana river basin was circularized on NOVOPlasty, but not from the São Francisco basin because of repeats on the D-loop region. Therefore, we uploaded the aligned reads to Galaxy and assembled de novo using SPAdes v3.13.0 (Bankevich et al., 2012). We blasted the sequences using megaBLAST implemented at NCBI obtained to be sure we had mitochondrial sequences (Altschul et al., 1990). We annotated the mitochondrial sequences on MitoAnnotator (Iwasaki et al., 2013) at MitoFish v. 3.60. We mapped as mitochondrial sequences in relation to the raw reads (after quality filtering) with Bowtie2 v. 2.4.1 (Langmead \& Salzberg, 2012).

To validate our data, we aligned the CDS sequences of the two individuals of $B$. nattereri, B. henni (GenBank NC_026873.1), B. orbignyanus (GenBank NC_024938.1), Salminus brasiliensis (GenBank NC_024941.1), and Astyanax paranae (GenBank NC_031380.1) (outgroup) using MUSCLE (Edgar, 2004), followed by maximum likelihood analysis using MEGA X software (Kumar et al., 2018), with GTR model + gamma + invariant sites and 1000 bootstrap.

\section{Dataset validation}

The mitochondrial genome of B. nattereri from Paraná and São Francisco river basin has the expected size for vertebrates, 16,837 bp (GenBank MT428073) and 16,752 bp (GenBank MT428074 access), respectively. Both specimens have a total of 37 functional genes (Figure 1), 13 DNA coding regions (CDS), two ribosomal RNAs and 22 transporter RNAs.

The maximum likelihood dendrogram generated with our data and other complete GenBank mitochondrial genomes (Figure 2) rescued phylogenetic relationships according to literature (Abe et al., 2014; Hilsdorf et al., 2008).

\section{Data availability \\ Underlying data}

Brycon nattereri voucher LAGEEVO_3928 mitochondrion, complete genome, Accession number MT428073.1: https://www. ncbi.nlm.nih.gov/nuccore/MT428073.1

Brycon nattereri voucher LAGEEVO_3847 mitochondrion, complete genome, Accession number MT428074.1: https://www. ncbi.nlm.nih.gov/nuccore/MT428074.1 

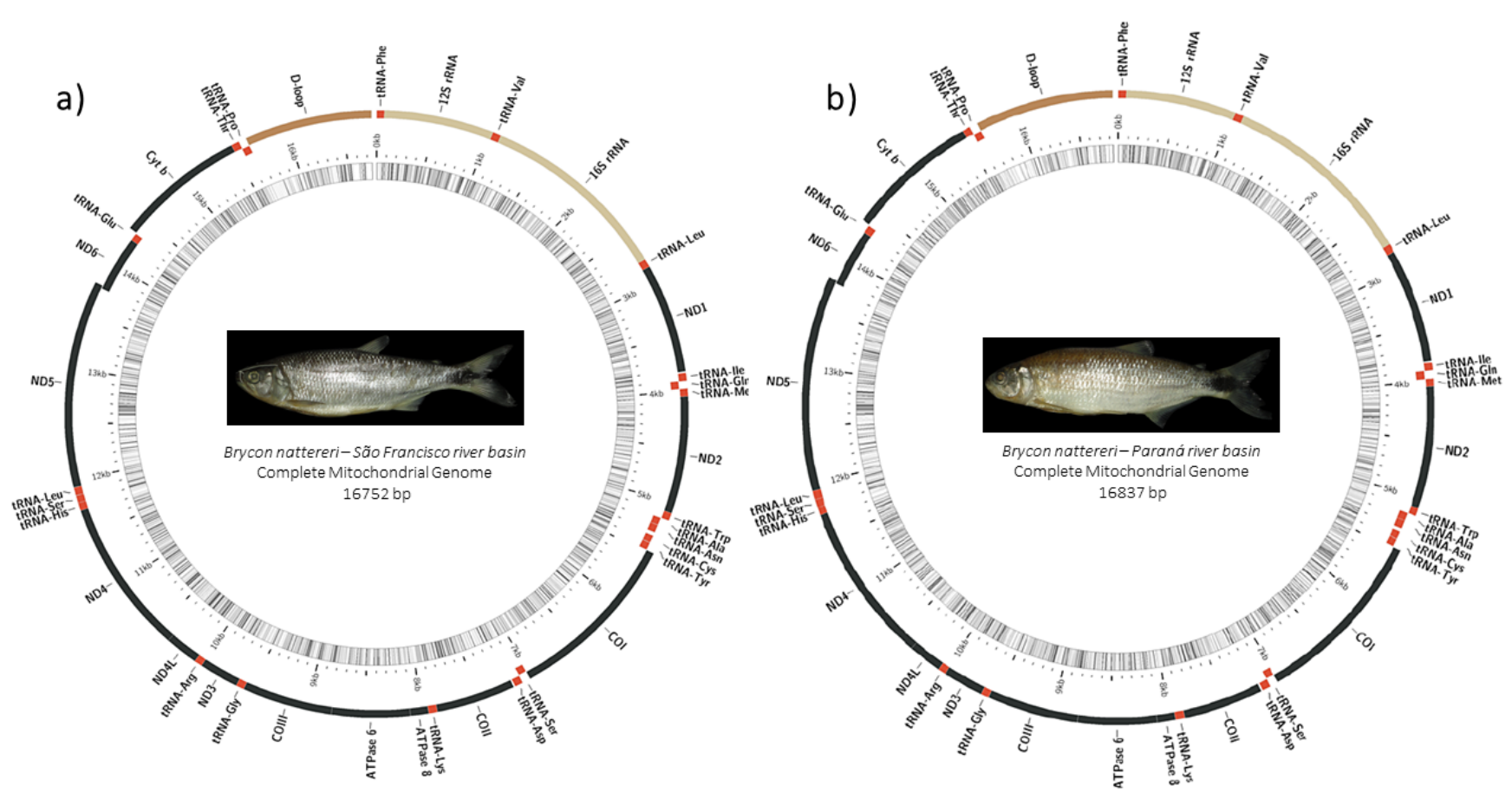

Figure 1. Illustrative diagram of the complete mitochondrial genome of Brycon nattereri from São Francisco (a) and Paraná (b) river basins, including genes encoding proteins, ribosomes and transporters, as well as their locations on the $\mathrm{H}$ and $\mathrm{L}$ strands.

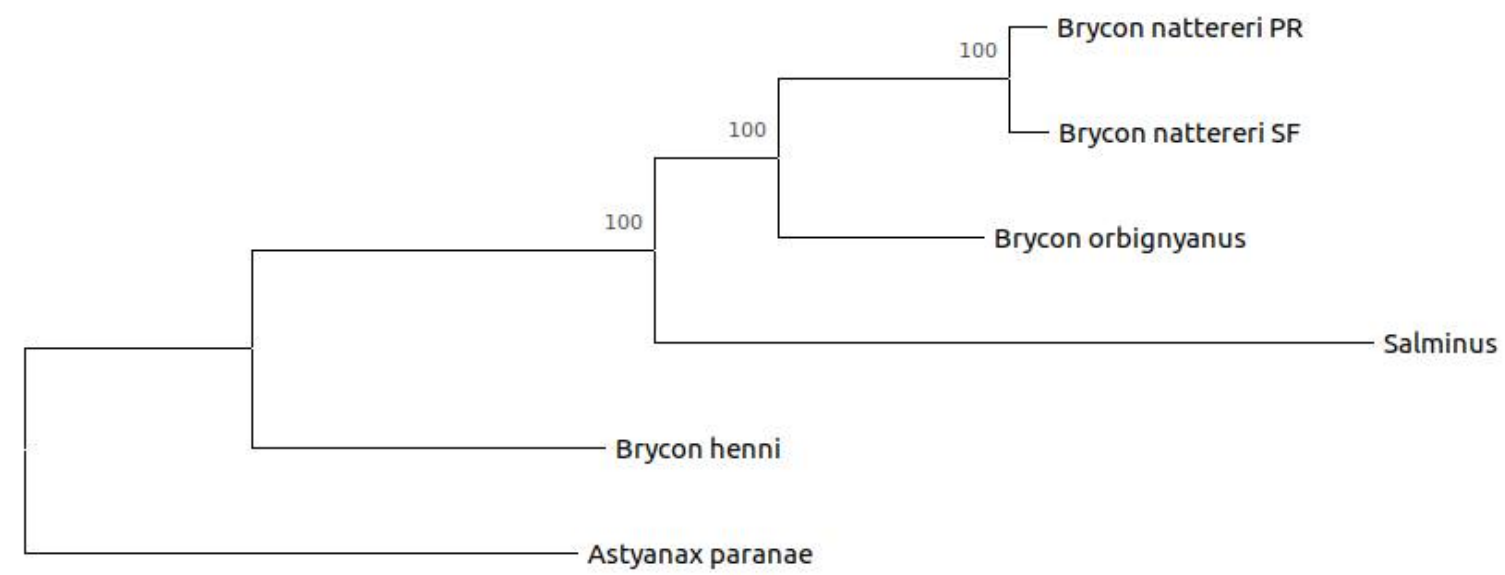

0.10

Figure 2. Evolutionary analysis by Maximum Likelihood method. The evolutionary history was inferred by using the Maximum Likelihood method and General Time Reversible model. The tree with the highest log likelihood (-45932.69) is shown. The percentage of trees in which the associated taxa clustered together is shown next to the branches. Initial tree(s) for the heuristic search were obtained automatically by applying Neighbor-Join and BioNJ algorithms to a matrix of pairwise distances estimated using the Maximum Composite Likelihood approach, and then selecting the topology with superior log likelihood value. A discrete Gamma distribution was used to model evolutionary rate differences among sites ( 5 categories $(+G$, parameter $=3.3372)$ ). The rate variation model allowed for some sites to be evolutionarily invariable ([+I], 43.41\% sites). The tree is drawn to scale, with branch lengths measured in the number of substitutions per site. This analysis involved six nucleotide sequences. Codon positions included were $1 \mathrm{st}+2 \mathrm{nd}+3 \mathrm{rd}+$ Noncoding. There was a total of 11549 positions in the final dataset. Evolutionary analyses were conducted in MEGA X. 
Acknowledgements

Authors thank Henrique Peluzio for his support on the UFV cluster. S.V.R. thanks to CAPES (Coordenação de
Aperfeiçoamento de Pessoal de Nível Superior) for the D.Sc. fellowship.
Abe KT, Mariguela TC, Avelino GS, et al: Systematic and historical biogeography of the Bryconidae (Ostariophysi: Characiformes) suggesting a new rearrangement of its genera and an old origin of Mesoamerican ichthyofauna. BMC Evol Biol. 2014; 14: 152.

PubMed Abstract | Publisher Full Text | Free Full Text

Afgan E, Baker D, Batut B, et al.: The Galaxy platform for accessible, reproducible and collaborative biomedical analyses: 2018 update. Nucleic Acids Res. 2018; 46(W1): W537-W544.

PubMed Abstract | Publisher Full Text | Free Full Text

Albrecht MP, Caramaschi É P, Horn MH: Population responses of two omnivorous fish species to impoundment of a Brazilian tropical river. Hydrobiol. 2009; 627: 181-193.

Publisher Full Text

Altschul SF, Gish W, Miller W, et al.: Basic local alignment search tool.J Mol Biol. 1990; 215(3): 403-410.

PubMed Abstract | Publisher Full Text

Bankevich A, Nurk S, Antipov D, et al.: SPAdes: a new genome assembly algorithm and its applications to single-cell sequencing. J Comput Biol. 2012; 19(5): 455-77.

PubMed Abstract | Publisher Full Text | Free Full Text

Bolger AM, Lohse M, Usadel B: Trimmomatic: a flexible trimmer for Illumina sequence data. Bioinformatics. 2014; 30(15): 2114-2120. PubMed Abstract | Publisher Full Text | Free Full Text

Botero-Botero A, Ramírez-Castro H: Ecologia trofica de la sabaleta Brycon henni (Pisces: Characidae) en el rio Portugal de Piedras, Alto Cauca, Colombia. Rev MVZ Córdoba. 2011; 16(1): 2349-2355.

Publisher Full Text

Dierckxsens N, Mardulyn P, Smits G: NOVOPlasty: de novo assembly of organelle genomes from whole genome data. Nucleic Acids Res. 2017;
45(4): e18.

PubMed Abstract | Publisher Full Text | Free Full Text

Edgar RC: MUSCLE: multiple sequence alignment with high accuracy and high throughput. Nucleic Acids Res. 2004; 32(5): 1792-1797.

PubMed Abstract | Publisher Full Text | Free Full Text

Hilsdorf S, Oliveira C, Lima FCTD, et al.: A phylogenetic analysis of Brycon and Henochilus (Characiformes, Characidae, Bryconinae) based on the mitochondrial gene 16S rRNA. Genet Mol Biol. 2008; 31(1): 366-371.

Publisher Full Text

Iwasaki W, Fukunaga T, Isagozawa R, et al:: MitoFish and MitoAnnotator: a mitochondrial genome database of fish with an accurate and automatic annotation pipeline. Mol Biol Evol. 2013; 30(11): 2531-2540.

PubMed Abstract | Publisher Full Text | Free Full Text

Kumar S, Stecher G, Li M, et al: MEGA X molecular evolutionary genetics analysis across computing platforms. Mol Biol Evol. 2018; 35(6): 1547-9.

PubMed Abstract | Publisher Full Text | Free Full Text

Langmead B, Salzberg SL: Fast gapped-read alignment with Bowtie 2. Nat Methods. 2012; 9(4): 357

PubMed Abstract | Publisher Full Text | Free Full Text

Lima FC: A revision of the cis-andean species of the genus Brycon

Müller \& Troschel (Characiformes: Characidae). Zootaxa. 2017; 4222(1):

zootaxa.4222.1.1.

PubMed Abstract | Publisher Full Text

Pavanelli CS, Bock CL, Oliveira $C$, et al. "Brycon nattereri Günther, 1864". In Instituto Chico Mendes de Conservação da Biodiversidade (Org.). Livro Vermelho da Fauna Brasileira Ameaçada de Extinção: Volume VI - Peixes. Brasília: ICMBio. 2018; 6: 85-88.

Resende SV, Silva IB, Pasa R, et al: Hidden evolutionary units and its implications on conservation in a vulnerable species of a freshwater fish. Zebrafish. 2020; In Press. 


\section{Open Peer Review}

\section{Current Peer Review Status: ? ?}

\section{Version 1}

Reviewer Report 01 November 2021

https://doi.org/10.5256/f1000research.29283.r96881

(C) 2021 Davies D et al. This is an open access peer review report distributed under the terms of the Creative Commons Attribution License, which permits unrestricted use, distribution, and reproduction in any medium, provided the original work is properly cited.

\section{Dora Davies}

Faculty of Natural Sciences, National University of Salta, Salta, Argentina

Juan José Lauthier

Research Council, National University of Salta, Salta, Argentina

The authors sequenced the mitochondrial genome of 2 specimens of Brycon nattereri, one of 7 threatened species out of 44 that the genus encompasses. The species is distributed in the basins of the Paraná and San Francisco rivers, in Brazilian territory. The specimens from tributaries of both basins show chromosomal, molecular and population differences. The genome size is that expected for vertebrates and shares $100 \%$ similarity between both samples.

Knowledge of the mitochondrial genome of specimens identified as Brycon nattereri is important taking into account its status as a threatened species of the Neotropical Region; however, the data shown in this work should be better explained, there's no further explanation about these discoveries and how they differ from other related organisms; the authors fail to relate these results to morphological and population data, considering that variations are known between individuals from different populations. For example, did the 2 individuals studied present morphological or chromosomal differences?

Is the rationale for creating the dataset(s) clearly described? Partly

Are the protocols appropriate and is the work technically sound? Yes

Are sufficient details of methods and materials provided to allow replication by others? Partly

Are the datasets clearly presented in a useable and accessible format? Yes 
Competing Interests: No competing interests were disclosed.

Reviewer Expertise: Morphological and molecular studies of parasitic helminths of freshwater fish and invertebrates (Davies) and Molecular and phylogenetic studies on parasites of clinical and ecological relevance (Lauthier).

\section{We confirm that we have read this submission and believe that we have an appropriate level of expertise to confirm that it is of an acceptable scientific standard, however we have significant reservations, as outlined above.}

\section{Author Response 29 Jul 2022}

\section{Snaydia Resende}

Dora Davies and Juan Jo'se, thank you for reviewing our manuscript. Brycon nattereri is listed as an endangered species and genetic studies are important for management and conservation programs. Our dataset provides specific mitochondrial markers that could be used in future projects with the species.

The main difference between the two mitochondrial genomes described here are correspond to the intergenic regions and the size of the D-Loop region, composed of 1197 bp (from 15640 to 16837) in B. nattereri from Paraná and 1112 bp in B. nattereri from São Francisco. In our maximum likelihood tree, we identified that there are phylogenetic differences between the two evolutionary units, as well as corroborating the hypothesis that the genus Brycon is not monophyletic.

In another work we had previously published with populations from the same localities (https://doi.org/10.1089/zeb.2020.1916), we identified chromosomal differences (the two evolutionary units show differences in karyotypic formulas, despite their conserved diploid number) and morphometric, where differences are also found in the body configuration of the two ESUs.

I would like to know what other details I can provide in the methodology to facilitate the replication of the work.

Competing Interests: No competing interests were disclosed.

Reviewer Report 23 December 2020

https://doi.org/10.5256/f1000research.29283.r75435

(c) 2020 Zhang Y. This is an open access peer review report distributed under the terms of the Creative Commons Attribution License, which permits unrestricted use, distribution, and reproduction in any medium, provided the original work is properly cited. 


\section{Yong Zhang \\ Department of Biology, University of Nevada, Reno, Reno, NV, USA}

This paper by Resende et al. sequenced the mitochondrial genome of the Brazilian fish species Brycon nattereri, which is endangered. This is the third sequenced mitochondrial genome for this genus. The data showed in this work is pretty straightforward and clear. However, the rationale for this study can be better explained. Main discoveries of the mitochondrial genome that differ this species from others should also be mentioned in the manuscript.

Is the rationale for creating the dataset(s) clearly described?

Partly

Are the protocols appropriate and is the work technically sound?

Yes

Are sufficient details of methods and materials provided to allow replication by others? Partly

Are the datasets clearly presented in a useable and accessible format?

Yes

Competing Interests: No competing interests were disclosed.

Reviewer Expertise: Genetics and molecular biology

I confirm that I have read this submission and believe that I have an appropriate level of expertise to confirm that it is of an acceptable scientific standard, however I have significant reservations, as outlined above.

Author Response 29 Jul 2022

Snaydia Resende

Thank you Yong Zhang for reviewing our manuscript.

Brycon nattereri is listed as an endangered species and genetic studies are important for management and conservation programs. Our dataset provides specific mitochondrial markers that could be used in future projects with the species.

The main difference between the two mitochondrial genomes described here are correspond to the intergenic regions and the size of the D-Loop region, composed of 1197 bp (from 15640 to 16837) in B. nattereri from Paraná and 1112 bp in B. nattereri from São Francisco.

I would like to know what other details I can provide in the methodology to facilitate the replication of the work. 
Competing Interests: No competing interests were disclosed.

The benefits of publishing with F1000Research:

- Your article is published within days, with no editorial bias

- You can publish traditional articles, null/negative results, case reports, data notes and more

- The peer review process is transparent and collaborative

- Your article is indexed in PubMed after passing peer review

- Dedicated customer support at every stage

For pre-submission enquiries, contact research@f1000.com 